\title{
Introducing a new series
}

\section{S D Small}

"The fox knows many things, but the hedgehog knows one big thing."1

host of salient figures stand out in the struggle against forces that pile up perceived injustice and resist change. These individuals can be counted on to illuminate dark places, mount a sustained often lifelong campaign, and leave a legacy of action, print, and story. Their substance continues to motivate and fuel others who challenge the status quo in the manner of great classic literature, defined by Pound as "news that is still news". ${ }^{2}$ Heroes and martyrs in the pantheon of health care take on added significance as the fight is for our bodies and souls. Those who have taken leadership roles in advancing quality and safety have often paid a personal price for their views and work, serving as lightning rods for social tensions, transforming issues of authority, power, accountability, ethics and professionalism.

In its evolution from the Greek martus, or witness, the word martyr came to refer to those who "witnessed" or openly testified to their religious beliefs, despite the consequences. It has come to mean generally one who suffers much in order to further a belief, cause, or principle. ${ }^{3}$ Safety culture has been said possibly to be the best and broadest defence against preventable harms, ${ }^{4}$ and as culture is thought to consist of a community's expressed values, beliefs, attitudes, norms and practices, there is fertile ground for martyrdom. There is also another nuance to the act of witnessing that is pertinent here, that has to do with giving credibility and helping to define and validate a reality which circumstances have conspired to conceal. Matters of risk and harm associated with medical management have preoccupied thinkers, actors, and patients for ages. However, the safety movement in health care accelerated dramatically in the mid 1990s due to a special convergence of forces including the information revolution, economic pressures, developments in other risky complex industries, and changing media and social expectations.

This first issue of the newly named Quality and Safety in Health Care pays testimony to these events. In the midst of rapid change and challenging old taboos, it is natural that today we look back to construct histories which help us make sense of where we are today, and how we might have arrived here. We gain coherence by identifying and acknowledging those whose work we continue to build on; we replenish our courage and our moral authority.

In the first installment of "Heroes and Martyrs of Quality and Safety" Duncan Neuhauser offers a deft sketch of Ernest Codman. It is of interest to reflect not only on Codman's famous principles, but on the strident tone of his message. As we attempt continuous improvement, it is important to keep in mind the importance of managing and leading change, productively negotiating inevitable conflicts and transforming rather than stoking adversarial relationships. In this sense, the figure of Codman may be said to be that much more tragic. Codman's harsh self-treatment after unwittingly ligating a hepatic duct- "I had made an error of skill of the most gross character"-lends itself as an example of the culture of perfection and, one might argue, the type of thinking which leads to superficial analysis of human failure in a complex task for which the constraints and affordances for action are incompletely known. It will require more than our best intentions to be transparent about our outcomes of care as we inherit Codman's legacy of publicising end results.

If the world is made up of foxes and hedgehogs, as Isaiah Berlin suggests, then surely Codman is a hedgehog-not "pursuing many ends, often unrelated and even contradictory, related by no moral or aesthetic principle" but "relating everything to a single, central vision, one system, in terms of which they understand, think or feel". ${ }^{5}$ The force and direction of his thought and purpose is reminiscent of a contemporary emerging philosophy of civil society in which safety is a code word for respect. Recent incarnations include the Swedish national road safety programme "Vision Zero", or no deaths due to crashes, and the Alcoa drive to eliminate completely injuries to company workers.

Future pieces in the series will feature incisive interviews with leading figures, additional historical vignettes, and reflections on the historiography of safety and quality in health care, or how history is made. The intention is not to subscribe to a "great man" theory of history, but to discover key themes in the pursuit of perfection and to honour those who have overcome prejudice to create new knowledge which has advanced the welfare of us all.

\section{Correspondence to:}

S D Small, Director, AHRQ Developing Centre for Research and Evaluation in Patient Safety and Lecturer in Law, University of Chicago Law School, Department of Anesthesia and Critical Care, University of Chicago Medical Centre, USA; ssmall@airway.uchicago.edu

\section{REFERENCES}

1 Archilochus. Frag 201. In: West ML, ed. Lambi et elegi Graeci. Volume 1. Oxford, 1971 lquoted in Berlin I. The hedgehog and the fox. Chicago: Ivan R Dee, 1993; reprint of George Widenfeld and Nicolson Ltd, 1953).

2 Pound E. The ABCs of Reading. New York: W W Norton \& Co, 1960.

3 The American Heritage Dictionary of the English Language. 3rd ed. Boston: Houghton Mifflin Company, 1992: 1104, 2051.

4 Department of Health. An organisation with a memory: report of an expert group on learning from adverse events in the NHS chaired by the Chief Medical Officer. London: The Stationery Office, 2000.

5 Berlin I. The hedgehog and the fox. Chicago: Ivan R Dee, 1993: 3 (reprint of George Widenfeld and Nicolson Ltd, 1953). 